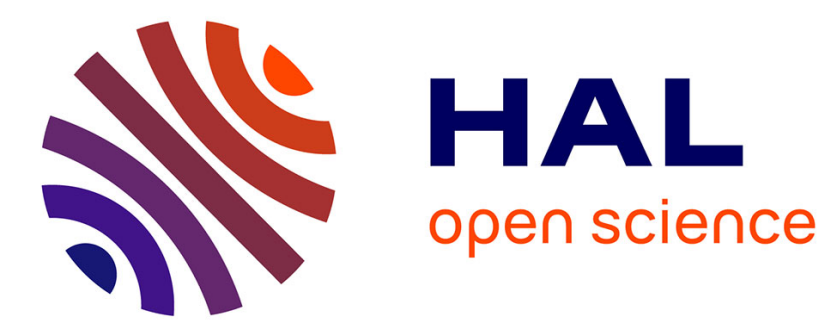

\title{
The Work and Workplace Analysis in an Elderly Centre for Agility Improvement
}

\author{
Arminda Guerra Lopes
}

\section{To cite this version:}

Arminda Guerra Lopes. The Work and Workplace Analysis in an Elderly Centre for Agility Improvement. 4th IFIP 13.6 Working Conference on Human Work Interaction Design (HWID), Jun 2015, London, United Kingdom. pp.153-167, 10.1007/978-3-319-27048-7_11 . hal-01371795

\section{HAL Id: hal-01371795 \\ https://hal.inria.fr/hal-01371795}

Submitted on 9 Nov 2016

HAL is a multi-disciplinary open access archive for the deposit and dissemination of scientific research documents, whether they are published or not. The documents may come from teaching and research institutions in France or abroad, or from public or private research centers.
L'archive ouverte pluridisciplinaire HAL, est destinée au dépôt et à la diffusion de documents scientifiques de niveau recherche, publiés ou non, émanant des établissements d'enseignement et de recherche français ou étrangers, des laboratoires publics ou privés.

\section{(c)(1)}

Distributed under a Creative Commons Attribution| 4.0 International License 


\title{
The Work and Workplace Analysis in an Elderly Centre
}

\section{for Agility Improvement}

\author{
Arminda Guerra Lopes, \\ Instituto Politécnico de Castelo Branco \& \\ Madeira Interactive Technologies \\ Institute, \\ Portugal \\ aglopes@ipcb.pt
}

\begin{abstract}
The mission of elderly services is to enable elders to live in dignity and to provide necessary support for them; to promote their sense of belonging, sense of security and sense of worthiness. The goals of the Portuguese social security system are to oversee the activities of non-public institutions for social solidarity and to improve the quality of operations and services. Conversely, it demands the alignment of the interaction process' collection, requirements and information system with those of the social centers for elderly. In this paper, we describe a workplace environment, a social center for elderly, and our strategy was, firstly, to understand the information flow in and out of the institution. We concluded that it needed to redesign and reconfigure his business process components, combining individual tasks and capabilities, in response to the environment (other social solidarity centers and the social security system) in order to improve agility. Secondly, we proposed a prototype interface, as new tool, to serve the communication process among the social centers for elderly and the national social security institution. This attempt may contribute to improve the interaction among the whole partners and to address organizations' agility and innovation.
\end{abstract}

Keywords: Work Analysis, Workplace, Agility, Information Systems, Information Technologies

\section{Introduction}

The long-term care system, in Portugal, until recently, was not integrated in the public sector. The Misericórdias (Holy Church), independent non-profit-making institutions with a religious background, provided the service. In order to expand services, a new private/public mix centered on the public subsidizing of non-profit institutions was created in the late 1980s. It was implemented through a new legislation on the legal status of non-profit provider institutions (designated as PISS - Private Institutions of Social Solidarity). In 2006, due to the increasing number of elderly persons and the reduced offer of these services, the National Network for Continuous Integrated Care adfa, p. 1, 2011

(C) Springer-Verlag Berlin Heidelberg 2011 
was implemented, based on the existing structure. The Ministry of Labor and Social Solidarity, in each Portuguese region, provided the social services. Health and social care services were, mainly, provided by private non-profit-making institutions (subsidized by the State) and by Misericórdias. Nowadays, there are various services and facilities available for the elderly: day-care centers, home-based services (home help and integrated home care that includes health care), nursing homes (long-term and palliative care) for highly dependent persons, and also residential care (protected flats) and family accommodation. However, the last two solutions are still very poorly developed.

In terms of information systems and technologies these institutions face several problems. The new technologies are not used properly for management, and conversely, the software development enterprises have single applications for each purpose: staff management, accounting management, vehicle management, and so on. Platforms that cover the whole information do not exist. Consequently, staff spends several hours filling and finding forms. On the other hand, the social security institution demands several reports to those institutions, which are difficult to prepare since information is spread over offices. For PISS, the quality management systems are outlined by the institutions of social solidarity as an important functioning guideline with all the rules that must be accomplished. However, there are bureaucracies to follow each time an intervention is made with the client. This takes an out-sized amount of information to deal with.

Facing this situation, and in order to contribute to sort specific problems of a private institution whose concerns were to increase its service quality, we proposed a technological solution, which was implemented, and later, tested and validated by the client. To arrive to the solution several steps were carried on such as the work and workplace analysis. The workplace analysis was determinant to improve quality of services, either for the employees or other stakeholders. It permitted to increase the levels of employees' motivation, and engagement. We questioned several factors to change the workplace environment - the intervenient requirements, needs, and workflow, in and out of the institution. Our methodology approached methods and techniques of human work interaction design.

The changes that occurred with our proposal contributed to improve institution agility. The institution's agility was addressed to increase institution and customers' services satisfaction. Conversely, the internal and external business processes were beneficiated by agility. Gartner stated that the main contributions considered by agility are customer service, security, knowledge management, asset management and cost efficiency [3].

\section{Theoretical Background}

The context for our study is the Portuguese Social Security System and the interactions with the private institutions of social solidarity. Those interactions are established either by paper format documents or by digital media of communication. We introduce, briefly, the Portuguese social security system its aims and relationships. We outline, also, the information systems and technologies as a tool to achieve organization agility. 


\subsection{The Portuguese Social Security System}

The literature is scarce about Portuguese studies in the presented field. We found some references about the third sector and the imperative of professionalization. Nonprofit organizations are defined and their objectives [23]; the social and solidarity environment is presented by [24], third sector dimensions in Portugal are described in the report "Portugal's Nonprofit Sector in Comparative Context" [25]. The information found was important to help to understand the functioning of these institutions and the interactions among the stakeholders.

In Portugal, the origins of several non-profit organizations were connected to the church, like Misericórdias [24]. The Misericórdias (holy houses of mercy) are an example of the strong cooperation between state and church, which has marked the history of Portuguese society in general. The statute of PISS is granted to organizations that are constituted "without a profit motive, on private initiative, with the purpose of giving organized expression to the moral duty of solidarity and justice among individuals" [25]. The social security system in Portugal is managed by the state and in principle, it applies to all individuals working in Portugal, either as employees or self-employed. It provides benefits for health care, sickness, retirement, disability, death, elderly, maternity, paternity and adoption. PISS helps children, young people and families. They support social and community integration, assist the elderly and disabled, promote and safeguard health, education and vocational training, and resolve housing problems.

The relationship between the social security system and the private institutions of social solidarity (PISS) is extremely important for their functioning. The social security makes, annually, agreements among institutions, the cooperation protocols, in order to answer the institution's demands. Besides these protocols, the social security elaborates quality manuals with guidelines to help institutions to create their own quality manual. The quality manuals are organized into validities: familiar housing, residential home, center of occupational activities, home of infancy and youth, residential center of temporary housing, structures for elderly, day-care centers, and domiciliary services support.

These models are an instrument of good practices to help the auto-evaluation of the social answers, permitting to review systematically its performance and to support the development and implementation of a quality management system to improve the functioning of each organization. Conversely, they are a normative referential for the requirements to a social reply, independently of the legal nature of the institution.

In Portugal, at reference point 31st December 2010, there were 5,800 owners' entities of social solidarity. Around $70 \%$ had non-profit goals. Among these, 61, 4\% were private institutions of social solidarity (which included the social services of enterprises and the 'Misericórdia' (Holy Church of Lisbon); 1,4\% were official entities, 2,1\% other private non-profit organizations and $3 \%$ were entities equivalent to PISS [26, 27].

In comparison with the residential care provided by the public sector, the nursing homes run by Misericórdias and other non-profit institutions are usually of better quality and only request a nominal contribution from patients and their families. Nur- 
sing homes in the private sector are very expensive and the majority of the population cannot pay for them.

Home care is expanding in Portugal and in some regions infrastructures to deliver support to the elderly have been developed in partnership with municipalities, regional health administrations and non-profit institutions. Apparently, the establishment of social care networks is becoming a priority.

The Portuguese government recognizes the relevance of PISS in the provision of social services to the population through the establishment of cooperation and financial agreements. In fact, the family support has been decreasing and the state considers the PISS a strategic part in the care system.

Afterwards, after understanding the main goals of these institutions, we analyzed, in loco, the communication forms and interactions among social solidarity institutions, and social security system to design a solution that would permit communication, easily, of the information shared among them.

\subsection{Information Systems and Technologies to Achieve Organizational Agility}

According to literature, the definition of agility is very broad, although its semantics converge. Along the last twelve or thirteen years we found that this concept started to be a common sense necessity between the academy and industry. However, agility is defined from different points of view and according different focus: Oosterhout et al. define agility focusing on business process unpredictable changes beyond flexibility levels [4]. Overby et al. describe agility as an ability that firms should have to sense environmental change and respond readily [5]. The response to the challenges posed by business environment dominated by change and uncertainty is the main aspect of agility. It helps the firm to be able to generate the required information for management decision-making. The speed in responding to variety and changes is the attempt to improve organizations' systems and architectures [6].

Considering agility within manufacturing, Jin et al. define it as the capability of surviving and prospering in a competitive environment of continuous and unpredictable changes by reacting quickly and effectively to changing markets, driven by customerdefined products and services [7]. Liu et al. refer agility emphasizing the supply chain as a form's ability to effectively collaborate with channel partners to respond to marketplace changes in a rapid manner [8]. Kalbande focus on business process agility highlighting e-procurement as the solution [9]. Sletholt gives another perspective: he emphasis agility practices in software development, and defines it as the responsiveness to change and collaborate [10].

Agility is very important since every organization must build agility to perform effectively in unstable environments. A set of processes that allow an organization to send changes in the internal and external environment, responding efficiently and effectively in a timely and cost-effective manner, and learn from the experience to improve the competencies of the organization is defined as organization's agility [11].

In order for information systems (IS) to act as an enabler of organizational agility, increasing the positive sides of information systems while minimizing the opaque sides, firms need to evaluate their information systems thoroughly, understand their dynamic environments, modify, and implement their suggestions [12]. Seo et al. identified several factors to minimize the called dark side of IS: standardization, buying, 
leasing or outsourcing, management skills, individual agility, organizational structure and culture. Once organizations analyze their own situations following the proposed factors, they will be agile since they learn in every cycle and it becomes their competency and flexibility.

Information Technologies (IT) is an important agility concern of many enterprises. The main reason for this is because the agile enterprise is collaborative since it communicates among its collaborators and stakeholders. Once IT is agile, several resources such as new tools, technologies and solutions including: cloud computing, collaboration technology, application portfolio management, and IT outsourcing will empower the agile enterprise [13]. Liu et al. studied the impact of IT capabilities on firm performance [14]. They underline the importance of supply chain agility, which is all about customer responsiveness in the uncertain market [15] and is essential in ensuring the firm's competitiveness because it enables effective and efficient responses to operational changes $[16,17,18]$.

IT capabilities are deemed as enablers to firm performance and the alignment between IT capabilities and strategy is increasingly important [19]. In fact, performance effects not only are affected by responding to environmental change, but also may be contingent upon the congruency between design choices and strategy [20].

Organizational and technical solutions help to achieve agility. However, besides the information technology sector being fundamental either for enterprise infrastructure, or for business process implementation and management it is not sufficient. The solution should fit with the enterprise agility needs and its specific situation. Information technology could be a barrier to business agility, the existence of inflexible systems is supposed to be a very important disabler in achieving more business agility. However, information technology enabled innovations, in general, and enterprise resource planning systems in particular, have contributed to the simplification, standardization and automation of business processes in the past [21].

\section{The Study}

This study adopts case study methodology to unveil the how questions in delving into the process of developing strategic Information Systems (IS) application. The process of unveiling strategic IS application is complex and multi-faceted, connected to each specific organizational context, comprises technological, complex human and social components [23].

The case study selection emerged from two conditions posed by our research questions. First, the case study had to have aimed to improve its workflows to interact with social security system. Second, the design process of our solution proposal should engage the whole intervenient to participate along the design process, in order to achieve a higher institution's agility practice.

Considering the prevailing situation about the interaction difficulties among the social solidarity institutions and the Portuguese social security system we attempted to fill the void to operationalize the agility practice by selecting as a case study, a small social center for elderly identified as SCLF.

The main goal of the SCLF, a private institution of social solidarity, is to help the clients who do not succeed to have, in their homes, the support conditions for the 
necessary care for a good quality of life. The SCLF offers several different services namely, residential structure for elderly, domiciliary support services, center of day, physiotherapy services and leisure activities for children until ten years old. The institution has a kitchen to prepare meals and is also responsible to supply and feed children of the village's school.

The center is organized as presented in figure 1. Two main groups can be distinguished, both having in charge the technical and services directors. The technical director area is divided into the technical bureau and the valences that the nursing house gives, namely the leisure center activities (LCA), day care center (DCC), domiciliary support service (DSS) and the residential structures for elderly (RSE). These services have different types of workers: direct help providers and service auxiliaries; the technical bureau has the health office with a physiotherapist, a doctor and nurse. The social office has a sociologist and in the leisure office there is a social educator. In the area supervised by the service director we have stocks management activities and the secretariat whose tasks are developed by the director. The kitchen has six cookers and the laundry is where service auxiliaries realize the tasks.

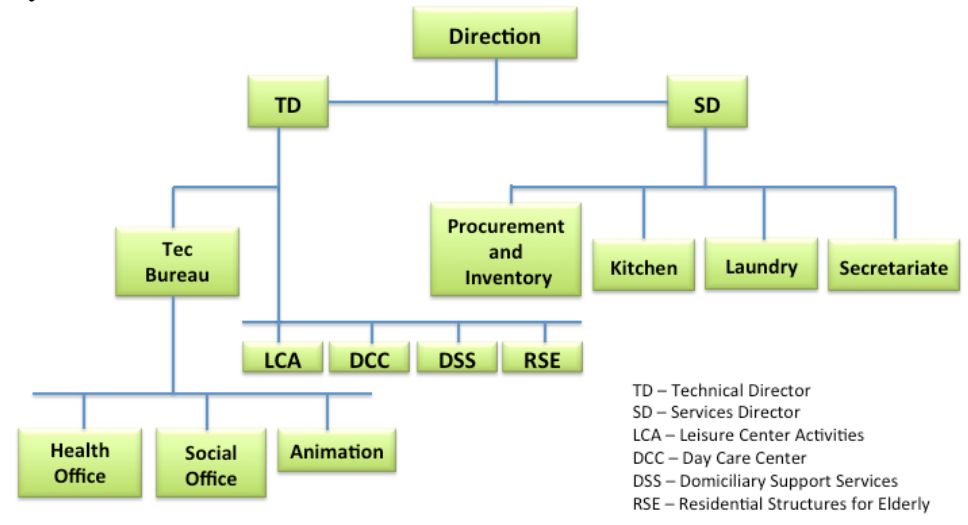

Figure 1 - Organogram SCLF

In order to explore the interactions context among the whole partners (users, collaborators, customers), we analyzed institutional documents and software applications; we use analysis and interviews and observations to understand the information flow among these organizations types, the employees, and user's needs. The interviews were recorded and additional notes were taken to provide more detail. To maintain interview originality and integrity, we conducted verbatim transcriptions. All the informants were provided with an assurance of confidentiality.

In the first phase, twelve semi-structured interviews were made to allow the interviewees a space of freedom to comment and/or present their concerns. The interviews were in a person-to-person interaction form. They were conducted in three social centres, (private organizations). (Table 1)

Table 1 - Total number of Interviews (Phase I)

\begin{tabular}{|l|l|l|l|l|}
\hline Institution & Interviewees & Interviews & Follow-ups & Total \\
\hline
\end{tabular}




\begin{tabular}{|c|l|c|c|c|}
\hline A & $\begin{array}{l}\text { Technical Director } \\
\text { IT Specialist }\end{array}$ & 1 & 1 & 4 \\
\hline B & $\begin{array}{l}\text { Service Director } \\
\text { IT Specialist }\end{array}$ & 1 & 1 & 4 \\
\hline C & $\begin{array}{l}\text { Service Director } \\
\text { IT Specialist }\end{array}$ & 1 & 1 & 4 \\
\hline Total & \multicolumn{3}{|c|}{$\mathbf{1 2}$} \\
\hline
\end{tabular}

Firstly, we prepared the text for the interviews and we selected the staff members of each institution according to a defined profile. After each set of interviews with people from the same profile (technical and/or services director \& IT specialist) in each of the three institutions, we analyzed the data and started to design first sketches of our prototype. Then, we interviewed the information systems technician of each institution. Another phase of interviews with the previous members of staff was made to consolidate and correct the gathered information.

In the second phase, at the SCLF, we undertook face-to-face interviews, which were conducted over a period of two months - a total 35 interviews. We used the same methodology, presented for first phase. We interviewed different staff members (directors, administrative staff, nurses...) (table 2).

Table 2 - Total number of Interviews (Phase 2)

\begin{tabular}{|c|c|c|c|c|}
\hline Institution & Interviewees & Interviews & Follow-ups & Total \\
\hline \multirow{10}{*}{ SCLF } & $\begin{array}{l}\text { Technical Director } \\
\text { IT Specialist }\end{array}$ & 2 & 1 & 3 \\
\hline & Technical Bureau Management & 2 & 1 & 3 \\
\hline & Service Auxiliaries & 1 & & 1 \\
\hline & Physiotherapist & 1 & 1 & 2 \\
\hline & Doctor & 1 & 1 & 2 \\
\hline & Nurse & 1 & 1 & 2 \\
\hline & Sociologist & 1 & & 1 \\
\hline & Social Educator & 1 & 1 & 2 \\
\hline & Service Director & 2 & 1 & 3 \\
\hline & Staff Manager & 2 & 1 & 3 \\
\hline
\end{tabular}




\begin{tabular}{|l|l|c|c|c|}
\hline \multirow{4}{*}{} & Cookers & 1 & & 1 \\
\cline { 2 - 5 } & Administrative Staff & 2 & 2 & 4 \\
\cline { 2 - 5 } & Secretary & 2 & 2 & 4 \\
\cline { 2 - 5 } & IT Specialist & 2 & 2 & 4 \\
\hline Total & $\mathbf{3 5}$ & & \\
\hline
\end{tabular}

Questions asked were exploratory in nature, open-ended, and tailored to the role of each interviewee. The first step was to sort the interview data into an initial set of themes. Sixteen questions were designed to gather information from the interviewees, either to understand the procedures and interactions in and out the institutions or to know the type of complains about the work situations experienced. We were interested, namely, to identify the kind of information that was necessary for users' management; the compulsory information to be exchanged between the institution and the social security system; the access points to consult information; people that should be involved in the process and the output documents that should be created.

The goal was to understand the difficulties that staff, in nursing homes, had when dealing with the whole amount of information that is spread all over the institution.

Finally, we interviewed the administrative people that will be in charge of the application's use. We also did a questionnaire to verify if the functionalities of our application were in consent with users. We intend to have suggestions about our layouts, functionalities, usability, and user's own comments.

\section{The Work analysis}

The backgrounds of work analysis came from the analysis of the process of collecting information about jobs [1]. Dierdorff and Rubin refer the theoretical issues associated with the work-related information to come to the term work analysis [2]. The change of the focus from jobs analysis to work analysis admits that the methods and concepts being applied in the workplace changes, as well as, the different situations that can be found. Work analysis can be approached within different perspectives: either as a methodology, a resource tool or a process. Work analysis data can be obtained from a widely collected type of human resources data in different organizations and/or during artifacts development. We used both as a process and resource tool.

The early focus on our interactive design process was the investigation about the workplace, the people, the technology, and the interactions among them. (To simplify we use the work 'people' meaning the whole individuals or groups that are involved in a process, being an employee, a customer, a staff, a patient or an institution). The workplace was analyzed considering the institution's characteristics: mission, goals, people, and different resources (technical, technological, finances, social, cultural). We tried to understand the different perspectives and aspects of the institution. The output gave us some of the information about the workplace environment. This pro- 
cess is what we consider the first contact with the work analysis in-between people and technology (Figure 2).

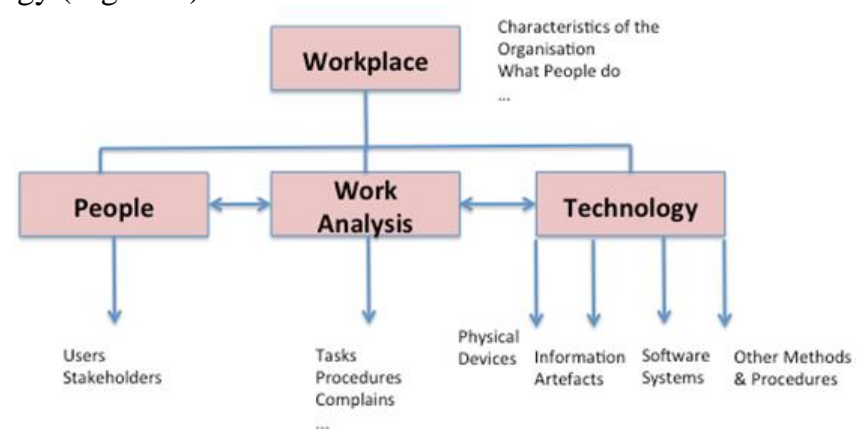

Figure 2 - Initial Data Analysis Framework

The work analysis are tasks, subtasks, activities, procedures, complains, needs, etc. The technology is the tangible or intangible output as the result of the interaction design process: it can be physical devices, information artifacts, software systems and other methods and procedures. The approaches to gather information about situations, users, customers, collaborators and other stakeholders were institutional documents, attitudes from the community (nursing houses and institutions of social solidarity) and software applications in use.

The data was, initially, collected following figure 2 and filling the information on table 3, which served as a guideline support to organize and objectivize the gathered information about the known and unknown situations. This table allowed ensuring a complete and holistic understanding of the institution's architecture.

Table 3 - Data Collection Table

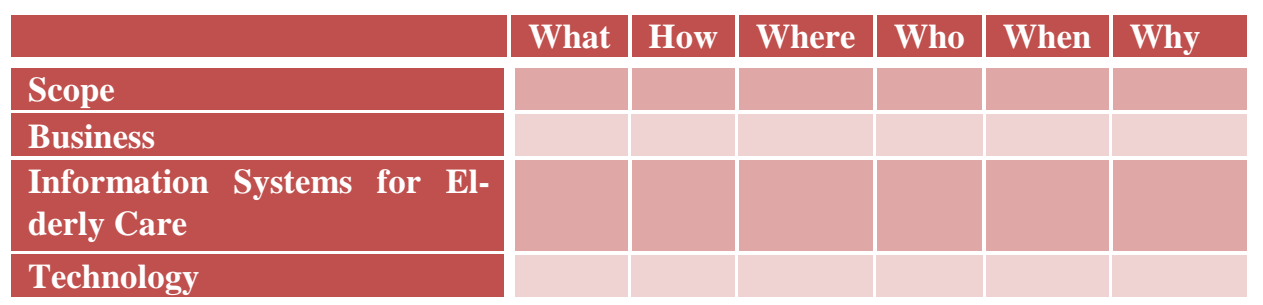

Table 3 is a four by six classification schema. The four rows represent different perspectives of the institution: its scope (vision, mission and objectives); the business characteristics and services; the main information systems and technologies used for elderly care and their features.

\section{The Results and Discussion}

After the institution first picture, obtained from the first interviews data, we refined our analysis and we organized the data according the information on figure (3). 


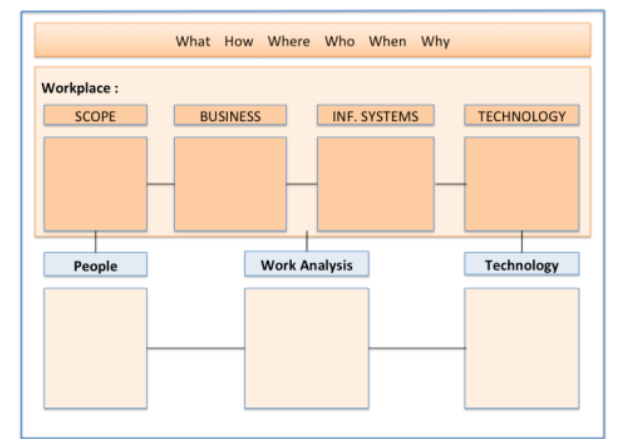

Figure 3 - Data collection framework

According our research we concluded that, in general, information was spread by different means of communication in a mixed of digital and paper forms. Social solidarity institutions do not interact, efficiently and effectively with the social centers for elderly due to the disaggregation of information systems and technologies. Almost all the institutions use different information technologies systems for management, accounting and other services. The human resources were scared for the amount of activities that social security demands. The human resources of these institutions had different backgrounds and experiences and, in general, they had few appetencies and were not motivated for technology use. In situations where they needed to exchange information, a diverse number of forms and documents were exchanged. They were also scared with the amount of activities that social security demands.

\subsection{Information Systems and Technologies}

Concretely, in the SCLF center, there were two software programs: one responsible for the accounting management and the other for user management. The former could only be functional for an accountant with some experience. The software had specific features, which do not permit a person who was not familiarized with accounting concepts, to use it properly. The software was divided into several areas; each one had its particular characteristics (Table 4). Several features needed constant updates according the new law decrees; and conversely, the compatibility issues with the supervisory bodies were not easy to make. In parallel with the difficulties of operating the software, users dealt with information exchange in paper format, which was not aligned with those in the software.

Table 4 - Accounting management software issues

\begin{tabular}{c|l}
\hline \multicolumn{1}{c|}{ Clients Control } & User Accounting Control \\
Waiting list to set properties & Automatic calculation (monthly) \\
\hline
\end{tabular}




\begin{tabular}{l|l}
\hline User registration (Documents Control) & Receipts issued from users \\
User Registration per valence (Docu- & Receipts issued from users with bar \\
ments Control & codes \\
Documents attachment (Various for- & Payments monitoring \\
mats) & Maps (IRS, current account, etc.) \\
Users misconduct control & General receipt control \\
& \\
\hline
\end{tabular}

The other software, the management software, was extremely complex due to its virtual use. Through this software users could create and record all parameters of the institution receipts and they could make the calculations about what each customer spends. A list with all the people on the waiting list could be drawn.

The main problems encountered with the information systems use were based on the absence of customization hypothesis, the lower experience and background of the institution's workers, and conversely, on the frequent legislation changes.

\subsection{Proposed Solution}

In order to help the social center (SCLF) to interact either with their stakeholders or with the social security system we proposed a prototype implementation for innovation in the organization. Staff took part sharing their personal knowledge with other stakeholders. We analyzed the characteristics of the environment, characteristics of the organization, characteristics of the people (staff and stakeholders) and the interactions along the processes as well as the needs of the people involved.

Table 5 summarizes the main issues we found and the proposed solutions to improve agility practices at SCLF.

Table 5 - Issues and solutions 


\begin{tabular}{|c|c|}
\hline $\begin{array}{ll}\text { - } & \text { Information systems disaggrega- } \\
\text { tion } \\
\text { - } & \text { Support conditions delivery } \\
\text { - } & \text { Different software packages } \\
\text { - } & \text { Procedures/Interactions } \\
\text { - } & \text { Information management: } \\
\text { - } & \text { Access points to consult infor- } \\
& \text { mation } \\
\text { - } & \text { Information exchange among in- } \\
& \text { stitutions } \\
- & \text { Complains } \\
\text { - } & \ldots \\
\end{array}$ & $\begin{array}{ll}\text { - } & \text { New layouts } \\
\text { - } & \text { New functionalities } \\
\text { - } & \text { New application design } \\
\text { - } & \text { New output documents } \\
\text { - } & \text { Reduction of paper use } \\
\text { - } & \text { Management tool for the communi- } \\
\text { - } & \text { Oation process } \\
\text { - } & \text { skilimisation of human resources } \\
\text { - } & \text { Framework design as a guideline for } \\
\text { - } & \text { Interactive application to manage } \\
& \text { intern information } \\
\text { - } & \end{array}$ \\
\hline
\end{tabular}

Considering the issues that were a concern for the institution and the solutions we found more suitable to achieve best agility practices, we proposed a prototype of an interactive application. This application integrates the whole information to be shared among institutions and users: administration, patient management, social care, doctors, nurses, the other help care providers and even the information about meals and food management. The information about each person's process, namely, the medical information, nursing information, social services information, physiotherapy, accounting, among others is organized and different users, those with permission, can consult it in an efficient way (Figure 4). The integration of services was highly complicated and controversial. The changes were progressively made with the collaboration of the staff. The information concerning the social area (social security services) was also included. Each month the system will deliver information maps about the different institutions interaction (waiting lists, client's allocation without institution place, etc.) Presently, the problems of mixed forms of communication were sorted. The difficulties we had with the communication among institutions and the social services were, almost, settled. 


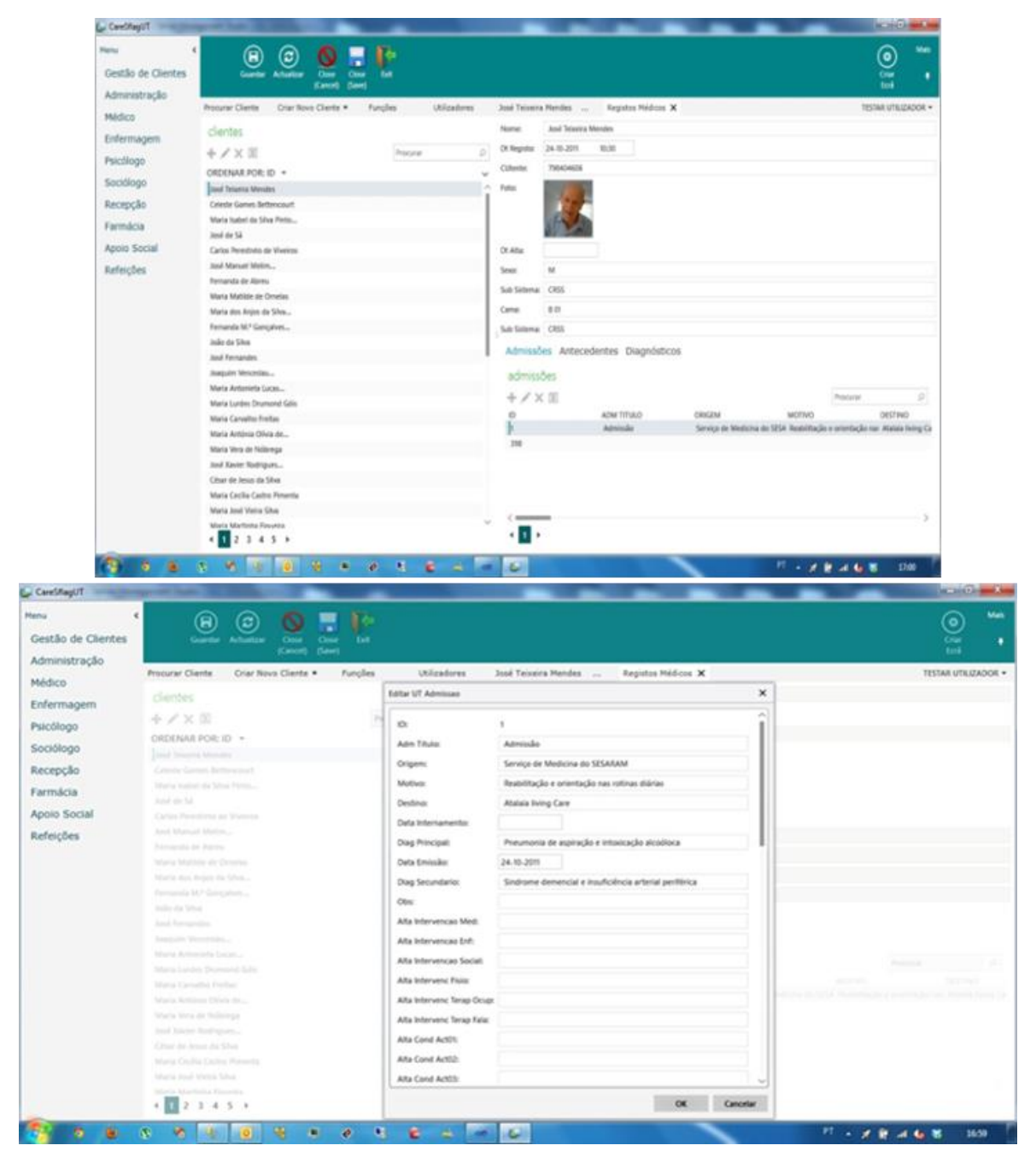

Figure 4 - Application Design

Afterwards, we designed a framework which could answer some of the problems, and the encountered needs (Figure 5). Firstly, it must be able to congregate all the areas and information necessary to center the whole necessities that can be performed in the institution. 


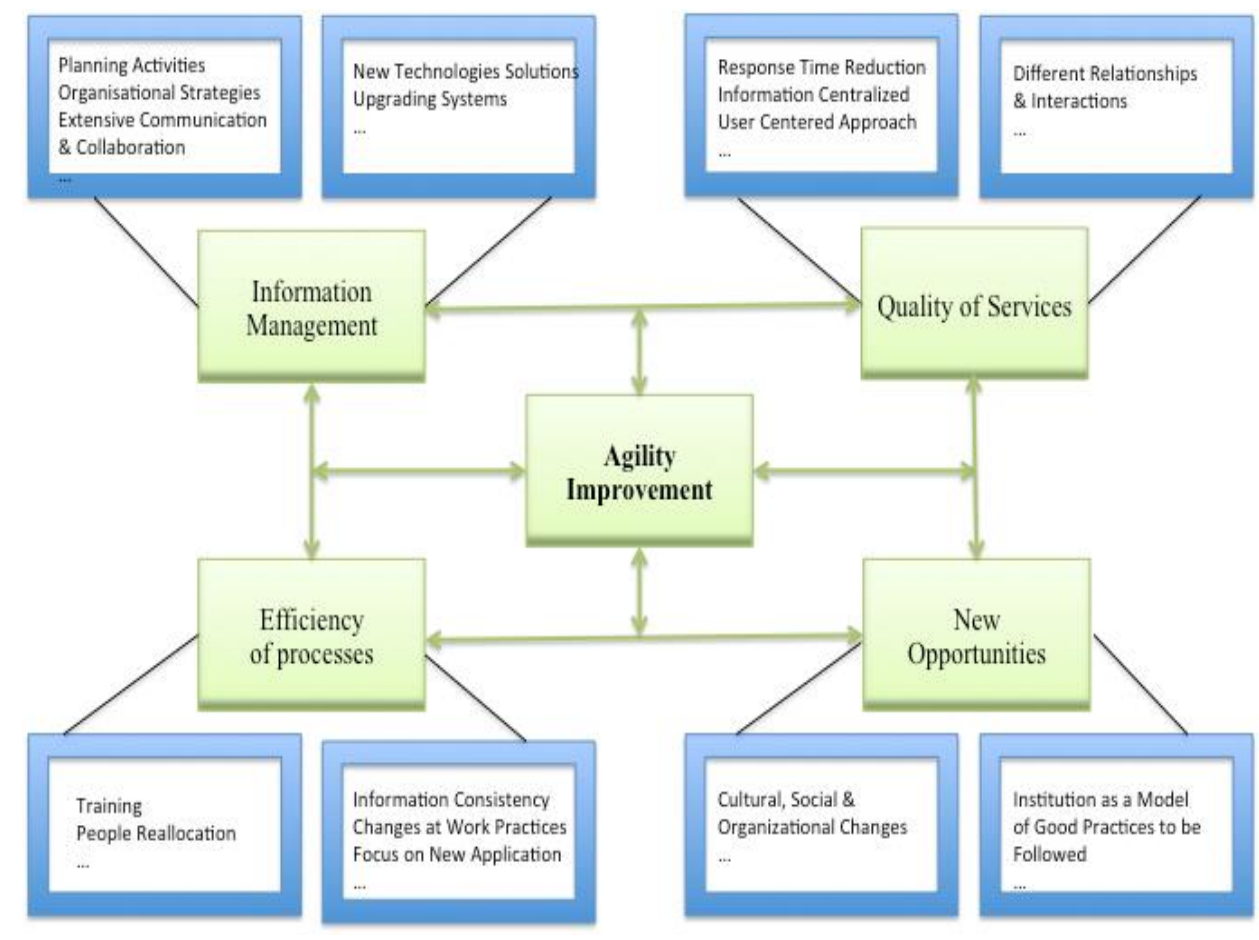

Figure 5 - Framework for agility improvement

\subsection{Pursuing agility}

The proposed approach contributed to introduce innovation on the social center through the alternative pathways of thinking and acting. The achieved changes permitted the organization to be agile. Every organization needs agility. An agile organization is one that senses change in the environment and responds efficiently and effectively to those changes in a timely manner. Moreover, to be agile is not straightforward, new systems, new business processes; even ways of working must be designed and implemented.

This study provided some design guidelines for building and applying interventions to increase agility in the described institutions. Many practices that promote agility already existed in the organization, but they needed to be deeply identified, improved where necessary and then aligned within an overall capacity-building strategy. Change-management practices were designed to promote agility, which were concentrated on creating an openness to change and assuring immediate execution of strategy by ending structural or cultural barriers that impeded the flow of work, people, resources and ideas.

The prototype solution was implemented on the SCLF center and then replicated on three other centers, until the moment. Information technology could generally be a 
barrier to business agility [28], and information technology may inhibit or allow agility [4]. We consider that these social centers are satisfied with the prototype proposal since they validate it. However, some improvements will be considered for the final application development. Agility was achieved through the organizational and technical solutions suggested.

\section{Conclusions}

One of the major insights we have reached within this study was that innovation methodologies were implemented across the social centers in interaction with the social security system. Human efforts engaged in the innovation process, tools, and technologies. The requirements, processes and outcomes were clearly defined and staff and employees were involved and motivated to this investment. The communication channels were identified and the structure of the innovation interventions process was defined.

The innovation introduced in the social center shown alternative pathways of thinking and acting; the majority never previously explored. Changes like involving employees, staff and other stakeholders in the discussion of the information flow were made. The communication among the information systems was established. The prototype of an interactive application for the center's management was implemented. We attained a final product development phase. As a result, a set of good practices was recognized and is, presently, followed by the whole intervenient in these institutions. Furthermore, the proposed solution acted as an enabler of organizational agility maximizing the gaps of communication in and out the institutions involved. Our results indicate that agility do promote organizational performance, though in somewhat different ways.

\section{Acknowledgments}

The author would like to acknowledge the work of Andre Alves. We would also like to thank all the interviewees and involves partners on the study.

\section{References}

[1] McCormick, E. Job Analysis, New York, American Management Association, (1979).

[2] Dierdorff, E. C., \& Rubin, R. S. Carelessness and discriminability in work role requirement judgments. Influences of role ambiguity and cognitive complexity. Personnel Psychology, 60: 597-625. (2007).

[3]Gartner, Will web services standards ever happen?, Gartner Report by M. Pezzini (2002). 
[4] Oosterhout, M., Waarts, E., Hillegersberg, J., Change Factors requiring Agility and Implications for IT, Published in: Journal European Journal of Information Systems - Including a special section on business agility and diffusion of information technology Volume 15 Issue 2, April 2006, pages 132 145, Macmillan Press Ltd. Basingstoke, UK. (2006).

[5] Overby, E., Bharadwaj, A., and Sambamurthy, V. (2006). Enterprise agility and the enabling role of information technology, European Journal of Information Systems, (15), 120-131.

[6] Gong, Y., and Janssen, M. (2012). From policy implementation to business process management: Principles for creating flexibility and agility, Government Information Quarterly, (29), S61-S71.

[7] Jin, K., Wang, T. and Palaniappan, A. Improving the agility of automobile industry supply chain, Proceedings of the 7th international conference on Electronic Commerce, ACM, 370-374. (2005).

[8] Liu, H., Ke, W., Wei, K. K., and Hua, Z. The impact of IT capabilities on firm performance: The mediating roles of absorptive capacity and supply chain agility. Decision Support Systems(2012).

[9] Kalbande, D.R., Thampi, G.T., and Deotale, N.T. E-Procurement for Increasing Business Process Agility, Proceedings of International Conference \& workshop on Emerging Trends and Technology (ICWET -ACM MUMBAI 25-26 Feb 2011), ACM. (2011).

[10] Sletholt., M., A Literature Review of Agile Practices and their Effects in Scientific Software Development, in SECSE, Waikiki, Havai, ACM. (2011).

[11] Dongback, Seo. Ariel. la Paz Exploring the Dark Side of IS in Achieving Organizational Agility. in Communications of the ACM: Vol. 51, 11. (2008).

[12] Seo, D., and La Paz A.I. Exploring the Dark Side of IS in Achieving Organizational Agility, Communications of the ACM, 51(11), 136-139. (2008).

[13] Gartner IT Glossary - Enterprise Architecture (EA). Gartner.com. Retrieved on July 29, 2013.

[14] Liu, Hefu, Ke, Weiling, Wei Kwok Kee, Hua Zongsheng, The impact of IT capabilities on firm performance: The mediating roles of absorptive capacity and supply chain agility, Journal of Decision Support Systems 54 (2013) 1452-1462.(2013).

[15] R. vanHoek, A. Harrison, M. Christopher, Measuring agile capabilities in the supply chain, International Journal of Operations \& Production Management 21 (1-2) 126-147. (2001).

[16] Agarwal, R. Shankar, M.K. Tiwari, Modeling agility of supply chain, Industrial Marketing Management 36 (4) 443-457. (2007).

[17] Sambamurthy, A. Bharadwaj, V. Grover, Shaping agility through digital options: reconceptualizing the role of information technology in contemporary firms, MIS Quarterly 27 (2) 237-263. (2003).

[18] Swafford, S. Ghosh, N. Murthy, The antecedents of supply chain agility of a firm: scale development and model testing, Journal of Operations Management 24 (2) 170-188. (2006)

[19] Hevner, A. R., S. T. March, J. Park, and S. Ram. "Design Science in Information Systems Research," MIS Quarterly, (28:1), pp. 75-106. 2004.

[20] Huang, P.-Y., Ouyang, T. H., Pan, S. L., and Chou, T. C. "The Role of IT in Achieving Agility: A case study of Haier, China," International Journal of Information Management (32), pp 294-298. 2012.

[21] Seethamraju, R., and Seethamraju, J. Enterprise Systems and Business Process Agility - A Case Study, 42nd Hawaii International Conference on System Sciences, HICSS '09, 1-12. (2009). 
[22] Tyrell, S. Using Information and Communication Technologies in Healthcare, Oxford, Radcliff Medical Press. (2002).

[23] Balonas, Sara. The Third Sector and the Imperative of Professionalization, European Social Marketing Conference, 27-28 November, Lisbon, Portugal. (2012)

[24] Azevedo, C.; Franco, R. \& Menezes, J. W. (Eds.) Gestão de Organizações Sem Fins Lucrativos - o desafio da inovação social, Porto: Imoedições. (2010).

[25] Lester M. Salamon, S. Wojciech Sokolowski, Megan Haddock and Helen Stone Tice, Portugal's Nonprofit Sector in Comparative Context 2002-2012, Johns Hopkins Center for Civil Society Studies in cooperation with Instituto Nacional de Estatística. (2012).

[26] Almeida, Vasco, Capitalism, Institutional Complementarities and the Third Sector, The Private for Social Solidarity (IPSS) in Portugal. (2008) at ttp://dspace.ism.pt/xmlui/handle/123456789/346

[27] Carta Social, Rede de Serviços e Equipamentos, Relatório 2010, Gabinete de Estratégia e Planeamento, Ministério do Trabalho e da Solidariedade Social. (2010).

[28] Seethamraju, R., and Seethamraju, J.. "Enterprise Systems and Business Process Agility - a Case Study," in: Proceedings of the 42nd Hawaii International Conference on System Sciences. IEEE Computer Society. (2009). 